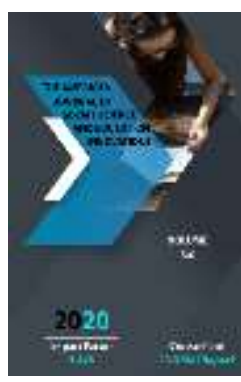

Journal Website: http://usajournalshub.c om/index,php/tajssei

Copyright: Original content from this work may be used under the terms of the creative commons attributes 4.0 licence.

\section{The Importance Of Military Patriotic Education In Higher And Secondary Special Educational Institutions}

\author{
Ilhom Erkinovich Erkinov \\ Teacher, (Major), Department of “Military Medical Training and Civil Protection", Samarkand \\ State Medical Institute, Uzbekistan
}

Alisher Sagdullaevich Kuchkorov Head of Department, Department of “Military Medical Training and Civil Protection", Samarkand State Medical Institute, Uzbekistan

\section{Azamat Nizamkulovich Atamurodov}

Teacher, Department of “Military Medical Training and Civil Protection”, Samarkand State Medical Institute, Uzbekistan

\title{
ABSTRACT
}

One of the urgent tasks of today is to educate young people in the spirit of patriotism, to prepare them physically and spiritually for the defense of the Motherland.

Organizes the organization, content, forms and methods of spiritual, political, psychological and physical training of students to serve in the Armed Forces of the Republic of Uzbekistan.

This article discusses the military patriotic education of students in higher education institutions. The information provided in the article also includes ideas on patriotic education of students and military personnel.

\section{KEYWORDS}

Military, military training, students, universities, physical training, mental training, patriotism, will, courage, bravery, devotion, love of country.

\section{INTRODUCTION}

Youth is the future of our Motherland, our nation. As we entrust the fate of our country to them, first of all, they must have a deep understanding of the complex and responsible task entrusted to them, and contribute to it. After all, love for the Motherland, love for it is directly determined by the creative work of everyone in the development of this country.

In the development of national identity, the education of thoughtful young people, imbued with the ideas of national patriotism, is of great importance. Therefore, each of our young 
people preparing for the defense of the Motherland must be brought up in the spirit of high patriotism. Patriotism is a high human quality.

\section{THE MAIN FINDINGS AND RESULTS}

Preparing young people for service in the Armed Forces of the Republic of Uzbekistan is a national task.

Military patriotic education gives good results only when it is carried out in a way that is inextricably linked with physical education.

Therefore, military patriotic education cannot be imagined without physical education. Tolerance to cold and heat, not to succumb to diseases quickly, to overcome difficulties, willpower. The role of physical education and sports in the development of students - young people and teachers - the qualities of the Defender of the Fatherland, such as perseverance, the ability to move fast and agile, are enormous.

One of the urgent tasks of today is to educate young people in the spirit of patriotism, to prepare them physically and spiritually for the defense of the Motherland.

Training of students in general education institutions, secondary special and secondary vocational education institutions, including students studying in higher education institutions in the spirit of military patriotism is now carried out through all systems of educational work.

One of the important tasks of the pedagogical staff of educational institutions is to provide students with theoretical and practical knowledge of military patriotic education, to prepare them for comprehensive military service and to fulfill their duty to protect the development of independent Uzbekistan. The subject "Military patriotic education" will help to solve it successfully.
Organizes the organization, content, forms and methods of spiritual, political, psychological and physical training of students to serve in the Armed Forces of the Republic of Uzbekistan.

The main tasks of the subject "Military patriotic education" are:

First, in connection with other disciplines studied in educational institutions, to educate students in the spirit of national patriotism to be always ready to go out with weapons in defense of their homeland;

Second, to develop pedagogical qualities in students, to cultivate active, conscious builders of a new society, people who are loyal to the ideas of national independence, hardworking, courageous and give their lives for their Motherland;

Third, to equip students with theoretical and practical knowledge on "Military patriotic education", to form in them the skills and abilities to organize and conduct educational work in a position typical of a teacher of "Primary Preparation for Conscription" in secondary schools, lyceums, colleges.

Issues of military patriotic education As a result of studying the subject of basic military training, students should know:

- Methods of organizing and conducting extracurricular activities, forms and methods, defense and sports activities during the "Primary training of youth before conscription" in secondary special and vocational education institutions;

- Organization and holding of "Vatanparvar Patriot", "Salomatlik - Healthiness" norms and "Shunkorlar - Braves" military sports games, conducting field exercises, celebrations dedicated to the end of the subject "Primary training of youth before conscription". 
- As a result of studying the subject "Military patriotic education" students should be able to:

- planning and implementation of activities on military patriotic education of students in secondary special educational institutions, ie the organization of trips to places where our people are famous for war and labor;

- arranging meetings with war and labor veterans, Armed

Meetings with troops;

- Conducting theoretical conferences on military patriotism, selection and preparation of candidates for study in military universities;

- Organization of military circles to learn the basics of military work.

In the process of studying this subject, each student must independently prepare 4-5 lectures (reports, abstracts) on the topic of military patriotism.

Extensive use of the rules of pedagogy and psychology in the military patriotic education of students is of great importance.

Military education is a complex sociopedagogical process, in which it is necessary to understand the following: to equip students with knowledge, skills and abilities; to cultivate in them the personal qualities necessary for an armed defender of their Motherland; to develop as a perfect person, to develop the skills of a creative approach to solving various tasks that arise, and to form the mental readiness to perform the tasks facing them and to act successfully in different situations.

At present, the content and process of military patriotic education should be enriched with the traditions of modernization of the educational system of the Republic, the acceleration of socio-economic development of the country, the growing role of human factors in the defense of the Fatherland.

The revision of the preparation of young people for the defense of the Motherland requires the full use of the content and organizational-methodological aspects of military patriotic education. Analysis of the effectiveness of educational activities, selection and consolidation of traditional forms given and tested by the practice of military patriotic education; it is necessary to look for new forms that will more fully implement the tasks of preparing young people for the defense of the Motherland in modern conditions.

Homeland readiness should not be seen as the result of special mass defense work, military sports games and other undoubtedly important forms of military patriotic education.

It is the result of the comprehensive development of the student's personality in accordance with the law, the assimilation by him of all the riches of social culture. When we talk about a healthy person, we mean not only physical health, but also a person with strong spiritual, moral and ethical norms, brought up in the spirit of the best universal examples.

Education plays an important role in the formation of all valuable and intellectual aspects of military patriotism. However, this theoretical conclusion is not fully applied in the practice of the work of teachers who teach the basics of science.

Teachers of general education take a superficial look at the tasks of military patriotic education and the possibility of the subjects they teach in solving these tasks. Training of defenders of the Fatherland is considered as a narrow specialization of the pedagogical team with the teacher "Primary training before the call", extracurricular defense - public events, the organizers of the LLC "Vatanparvar". 
But if the student is not closely acquainted with the life of the military during his studies, if he is not inspired by the lofty goals of consolidating peace, strengthening the country's defense, it may not be effective to understand and supplement them through small "events". can grow as a citizen.

The activity of the pedagogical staff of educational institutions in the study of this topic, that is, in the upbringing of patriotic youth who are ready to defend their homeland with weapons in their hands, is unparalleled.

Military patriotic education is conducted in educational institutions for the following purposes:

- Formation of devotion to the people, deep respect for the history and traditions of the Motherland;

- Education in the spirit of unconditional implementation of Presidential Decrees, laws and resolutions of the Oliy Majlis and the Government of the Republic of Uzbekistan; - Propagation of the traditions of military patriotism of the peoples of Uzbekistan, love for military service and the army, high moral and combat qualities, personal responsibility in the implementation of the Military Oath and Military Regulations, as well as courage, discipline, intelligence, constant readiness to defend their homeland.

The main content of military patriotic education:

- Citizens of the Republic of Uzbekistan in defense of the homeland

Explain the constitutional duty;

- To get acquainted with government decisions on further strengthening of the defense of the Republic of Uzbekistan;
- Explain the issues to be addressed by the Armed Forces of the Republic of Uzbekistan and their tasks and features;

- Study and master the main requirements of the Law of the Republic of Uzbekistan "On General Military Obligation and Military Service", the Military Oath and Military Regulations;

- Explain the goals and objectives of preparing young people for military service;

- Propagation of ancestral heritage, great and brave ancestors - martial traditions of our ancestors.

The process of patriotic education in secondary special education institutions plays a leading role, has a great impact on the formation of the future Defender of the Fatherland, because the content of educational disciplines reflects the important spiritual, moral and cultural traditions of our people. But it is not enough to limit this process to separate components of patriotic education. He must be ready to defend the Motherland, to have a comprehensive and active practical influence on the state of all its components, and to help them understand this readiness as the most important aspect of a teenager's life.

\section{CONCLUSION}

It is necessary to equip patriotic youth with a system of knowledge that will ensure the mastery of the basics of national defense, because one of the important tasks of the educational process is the formation of national defense as a strong and courageous defender. Students will be introduced not only to military knowledge, but also to criteria that, at first glance, are directly related to the problems of the army, military construction, war, and peace. Based on the combination of different disciplines (history, physics, mathematics, etc.), they form a basic understanding of the knowledge and skills necessary for the Defender of the Fatherland. 
The content of military patriotic education in secondary special education institutions consists of the doctrine of Defense, Military Oath, Military Regulations, laws and general education, as well as special disciplines (basic pre-service training, civil defense). .

Military patriotic education in educational institutions should be carried out at all levels.

\section{REFERENCES}

1. Sh. Mirziyoev. Speech at the Security Council on "Our Armed Forces - a strong guarantee of stability and development of our country." // - People's Word newspaper. 2018, №3. (Sh.Mirziyoev. Speech at the Security Council on "Our Armed Forces - a strong guarantee of stability and development of our country." // - People's word newspaper. 2018, №3)

2. Decree of the President of the Republic of Uzbekistan No. PF-4947 of February 7, 2017 "On the Strategy of Actions for the Further Development of the Republic of Uzbekistan" // www.lex.uz. (Decree of the President of the Republic of Uzbekistan dated February 7, 2017 No PF-4947 "On the Action Strategy for further development of the Republic of Uzbekistan" // www.lex.uz)

3. Nasriddinov Ch.R. Military psychology. Tashkent. "Fan" publishing house 2004. (Nasriddinov Ch.R. (2004) Military psychology. - Tashkent. "Fan" publishing house)

4. Sadulla Otamurodov, Sarvar Otamurodov. Spiritual revival in Uzbekistan. Tashkent. Yangi Asr Avlodi Publishing House 2003. (Sadulla Otamurodov, Sarvar Otamurodov. (2003) Spiritual recovery in Uzbekistan. Tashkent. Yangi Asr Avlodi Publishing House)

5. Fundamentals of military-patriotic education. Marifat Publishing House 1988. (Fundamentals of military-patriotic education. Ma'rifat Publishing House 1988)

6. E.Umarov, M.Abdullaev. Fundamentals of spirituality. Sharq Publishing House, 2005.
(E.Umarov, M.Abdullaev. (2005) Fundamentals of spirituality. Sharq Publishing House)

7. Instructions of the Minister of Defense of the Republic of Uzbekistan D-7, D-16, D-17. 2003 (Instructions of the Minister of Defense of the Republic of Uzbekistan D-7, D-16, D-17. 2003)

8. Inoyatov I.Yu., Abilov M.Kh. "Sacred corner of the homeland" Tashkent.

"Uzbekistan". 2001 (Inoyatov I.Yu., Abilov M.X. (2001) "Sacred duty to defend the homeland." - Tashkent. "Uzbekistan”)

9. The Republican Center for Spirituality and Enlightenment said, "A free and prosperous life cannot be built without high spirituality." Tashkent. "Uzbekistan". 2006 (Republican Center for Spirituality and Enlightenment "A free and prosperous life cannot be built without high spirituality". - Tashkent. "Uzbekistan". 2006)

10. Raven D, B., \& Martin, M. M. (1994). Development of a measure of interpersonal communication competence. Communication Research Reports, 11, 33-44.doi: 10.1080 / 08824099409359938 /. Doll, Y. (2007). U.S. Armywomen general officers and their strategies for ascension. International Journal of Business Strategy, VII (3), 1-10. 